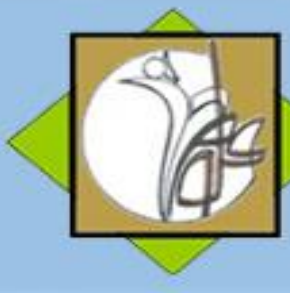

\title{
Psychometric Properties of Persian Version of the Exercise Dependence Scale-Revised (EDS-R) in Bodybuilders
}

\author{
Lida Motaghian ${ }^{1}$, Saman Nonahal ${ }^{2}$. Reza Moloodi ${ }^{3}$, Jafar Hasani ${ }^{4}$
}

1. Lida Motaghian, (M.A) Roudehen Islamic Azad University, Iran

2. Saman Nonahal, (Ph.D. Student) Kharazmi University, Tehran, Iran

3. Reza Moloodi, (Ph.D. Student) University of Social Welfare and Rehabilitation Sciences, Tehran, Iran

4. Jafar Hasani, (Ph.D) Kharazmi University, Tehran, Iran

\section{ARTICLE INFO}

Received January 2017

Accepted August 2017

\section{KEYWORDS:}

Exercise Dependence

Scale-Revised

Psychometric Properties

Body Building

\section{CITE:}

Motaghian, Nonahal, Moloodi, Hasani, Psychometric Properties of Persian Version of the Exercise Dependence Scale-Revised (EDSR) in Bodybuilders, Research in sport management \& motor behavior, 2020: 9(18)197-212

\section{ABSTRACT}

The purpose of the present study was to evaluate reliability and validity of Persian version of the Exercise Dependence Scale-Revised in Gorganian Bodybuilder men. After a rigorous translation and back-translation procedure, 400 men completed the Drive for Muscularity Scale (DMS), the Exercise Dependence Scale-Revised (EDS-R), the Eating Disorders ExaminationQuestionnaire (EDE-Q), and the Clinical Impairment Assessment (CIA). The reliability of the scale was assessed via internal consistency. Cronbach's alphas range (0.76 to 0.82 ) suggested good reliability of the Persian version of EDS-R. Confirmatory factor analysis supported the original seven factor model of the scale. The internal relations between the subscales ( 0.22 to 0.59$)$ and concurrent validity ( 0.09 to 0.78 ) also were appropriate. The Persian version of the Exercise Dependence Scale-Revised has a satisfactory psychometric properties in the Iranian society and useable in the clinical and research settings. 


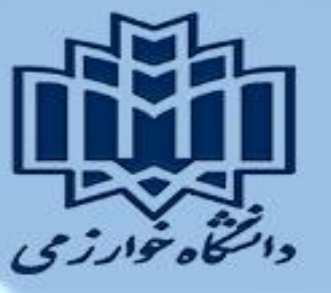

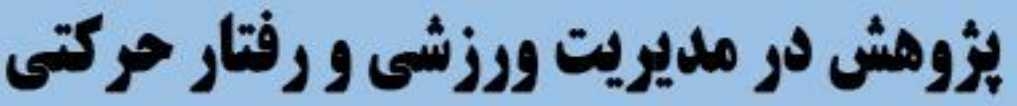

\section{ويزگى هاى روان سنجى نسخهُ فارسى مقياس تجديدنظر شدهُ وابستكى به تمرين در يرورشاندامكاران \\ ليدا متقيان'، سامان نونهال؟، رضا مولودى"، جعفر حسنى

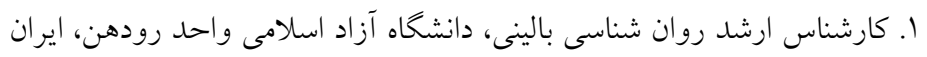

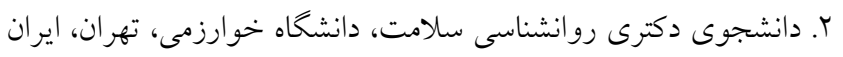

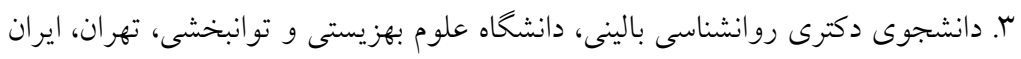

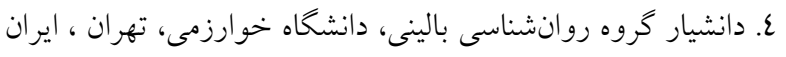

هدف از اين يزوهش، بررسى ويزگگى هاى روانسنجى نسخة فارسى مقياس تجديد نظرشده وابستكى به تمرين در ورزشكاران رشتهُ يرورشاندام بود. به اين منظور، . .ع نقر از ورزشكاران مرد رشتهُ يرورشاندام، به صورت در دسترس انتخاب شدند و به مقياس تمايل به عضلانى بودن، مقياس تجديد نظرشده وابستكى به تمرين، تبرسشنامة بررسى اختلالهاى خوردن، و مقياس اختلال در عملكرد، يِاسخ دادند. اعتبارِ مقياس، بر اساس همسانى درونى بررسى شد. دامنهُ آلفاى

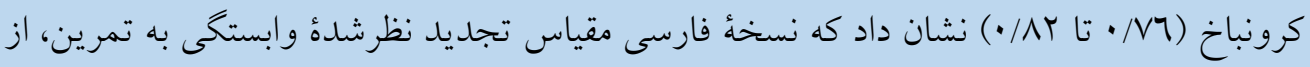
اعتبار مطلوب برخوردار است. تحليل عاملى تأييدى، از الخوى هفت عاملى مقياس تجديد نظرشده

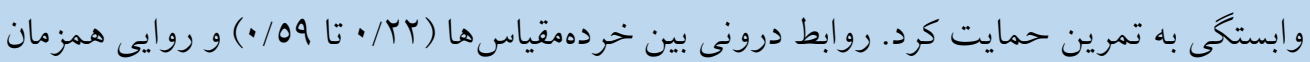

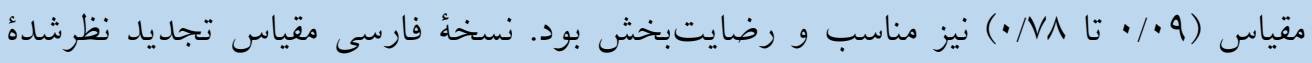
وابستكى به تمرين، ويزگى هاى روانسنجى رضايتبخشى در جمعيت ايرانى دارد و در موقعيت هاى مختلف بالينى و يُزوهشى، قابل استفاده است.
اطلاعات مقاله:

دريافت مقاله دى 90بr

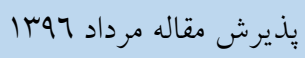

ث*ونسنله مسئول:

hasanimehr57@yahoo.com

وازه هاى كليدى:

مقياس تجديد نظرشدة وابستكى به تمرين ويز كىهاى روان سنجى

يرورش اندام

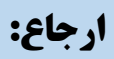

متقيان، نونهال، مولودى، حسنى. ويزٔگى هاى روان سنجى نسخة فارسى مقياس تجديدنظر شده وابستكى به تمرين در برورشاندام كاران. يُروهش . در مديريت ورزشى و رفتار حركتى،

rIr-19V:(1N) $9:$ Irq1 


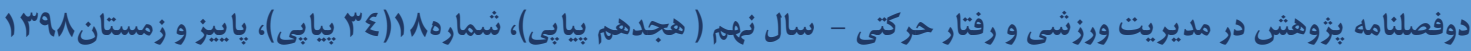

مقدمه

نتايج بسيارى از يزوهشها حاكى از آن است كه اجراى تمرينات ورزشى، با تندرستى و سلامت روان ارتباط دارد ( ( Y)؛ با اين حال، اگر در اجراى آن زيادهروى شود ممكن است آثار جسمى (مانند كمخونى) و روانى (مانند افسردگى) مخربى را به همراه داشته باشد (r). تمركز اصلى يزوهشخرانى كه به بررسى آثار روانى مخربِ ورزش مىيردازند بر مسألهاى است كه وابستكى به تمرين ا نام دارد. مشخصهُ وابستخى به تمرين ميلٍ شديد به تمرين است. اين ميل، تمرينات افسار كسيخته را موجب مىشود و اين تمرينات، به علايم جسمى، روانى، يا هردو دامن مىزنند (ع). آثار زيانبار وابستخى به تمرين، يُزوهشكران را بر آن داشت تا براى سنجش جنبه هاى مختلف آن، ابزارى تدوين كنند. تلاشهاى آنان به

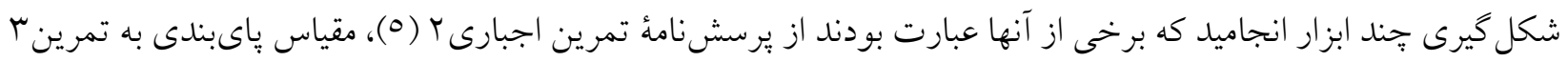

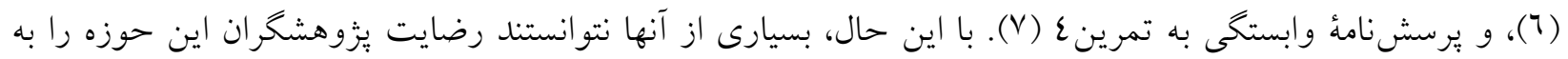
خود جلب كنند و در نتيجه با انتقادهاى مختلفى روبهرو شدند. براى مثال، برخى معتقد بودند آنها وابستخى به تمرين را سازهاى تكىبعدى تعريف و در يك بيوستار مفهوميردازى كردهاند. بنابراين، قادر به شناسايى يا طبقهبندى مبتلايان به آن نيستند. بهعلاوه، اغلب آنها از ملاكهاى راهنماى تشخيصى و آمارى اختلالهاى روانى - ويراست ع براى وابستكى به مو اد استفاده نكردهاند ( ع). براى رفع جنين نقصهايى، اقدامات مختلفى صورت گرفت. يكى از آنها به يزوهش هازنبلاس

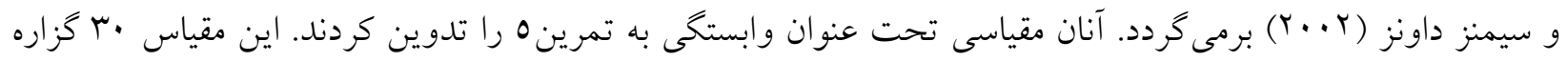
داشت. اين گزارهها بر اساس ملاكهاى راهنماى تشخيصى و آمارى اختلالهاى روانى - وير است ع براى وابستخى به مواد تدوين شده بود. بر مبناى اين مقياس مىشد بين سه كروه از افراد تمايز قايل شد: ( (1) در معرض خطر ابتلا به وابستىى به تمرين، (Y) واجد برخى از علايم وابستخى به تمرينج، (T) عارى از علايم وابستخى به تمرين V. خردهمقياسهاى آن عبارت بود از نشانهاى تحمل ^، علايم ترىه، قصد · ( فرد بيشتر از آنجه كه مورد نظرش است، تمرين مىكند)، كنترل نداشتن بر تمرين |l، افزايش زمان تمرين Y|، كاهش فراواني ساير فعاليتهاسا، و تداوم تمرين به رغم بروز مشكلات

1. exercise dependence

2. Obligatory Exercise Questionnaire

3. The Commitment to Exercise Scale

4. Exercise Dependence Questionnaire

5. Exercise Dependence Scale (EDS)

6. nondependent-symptomatic

7. nondependent-asymptomatic

8. Tolerance

9. Withdrawal

10. Intention Effect

11. Lack of Control

12. Time

13. Reductions in Other Activities

https://jrsm.khu.ac.ir/ 


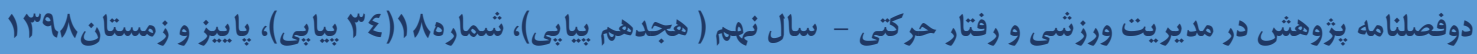

جسمانى ع ا. بعد از تدوين مقياس وابستكى به تمرين، تلاشهايى براى وضوح هر تهه بيشتر گزارههاى آن صورت گرفت. اين تلاشها باعث شد تعداد گزارههاى اين مقياس به اب گزاره كاهش يابد (N). نتايج يزوهشى كه داونز، هازنبلاس، و

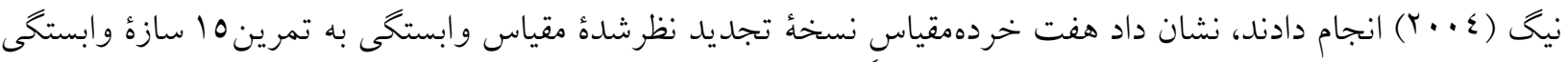
به تمرين را آن كونه كه راهنماى تشخيصى و آمارى اختلالهاى روانى - ويراست ع براى وابستكى به مواد در نظر كرفته است، اندازهيرى مى كند. همجِنين نشان داد كه اين خردهمقياسها از همسانى درونى و اعتبار آزمون- بازآزمون رضايتبخشى (به ترتيب ra/ • و 190•) برخوردار است. شايان ذكر است كه اين يزوهش نشان داد عاملهاى نسخهُ تجديد نظرشده مقياس وابستخى به تمرين ارتباط مستقيم، قوى، و معنادارى را با همديخر نشان مىدهند. براى مثال، ميزان ارتباط بين عامل هاى قصد، افزايش زمان تمرين، كاهش فراوانى ساير فعاليتها، و نشانههاى تحمل از • • • تا VA/ • متغير بود. نتايج مذكور اين احتمال را مطرح مى كند كه هفت عامل ياد شده، مفهومى يك بعدى را اندازه گيرى مىنمايد. بنابراين، داونز و همكاران (N) در اين يزوهش، نسخهُ تجديد نظرشدهُ مقياس وابستكى به تمرين را ابزار غربالخرى معرفى كردند.

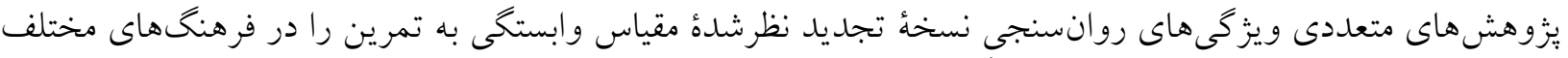

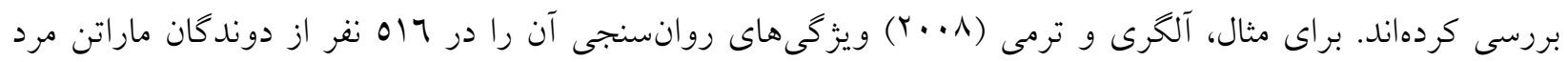
فرانسوى بررسى كردند. يُزوهش آنان نشان داد مدل هفت عاملى كه داونز، هاوزبلاس، و نيخ بيشنهاد كردهاند، با دادهها هماهنگ است. در يُزوهشى ديكر، مولر و همكاران (•l) ويزَّى هاى روانسنجى مقياس مذكور را در آلمان به محك

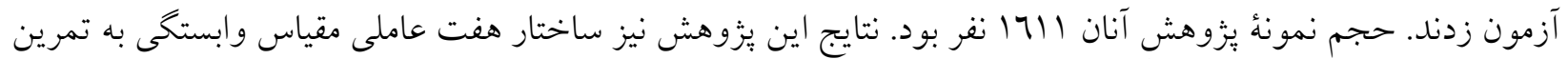
را تأييد كرد. به علاوه، نشان داد كه يك عامل سطح بالاتر، تمام خردهمقياسها را در بر مى گيرد. يزوهشخران همرجنين كزارش كردند كه اين مقياس از همسانى درونى رضايتبخشى برخوردار است و با برسشنامُٔ بررسى اختلالهاى خوردن ارتباط مثبت و معنادارى دارد. ياراستاتيدو، دو گانيس، تئودوراكيس، و ولاكويولوس (1) نيز به بررسى ويزگى هاى روانسنجى اين مقياس در ورزشكاران يونانى برداختند. حجم نمونهُ اين يزوهش داد كه مدل هفت عاملى، بهطور مناسبى با دادهها هماهنگ است و اين عامل ها از همسانى درونى و اعتبار آزمون- بازآزمون رضايتبخشى برخوردارند. ويزگىهاى روانسنجى نسخهُ تجديد نظرشده مقياس وابستخى به تمرين در ورزشكاران

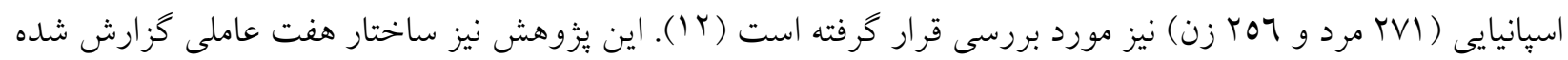
و يكى عامل سطح بالاتر را كه در يُوهشهاى قبلى آشكار شده بود، تأييد كرد. اما نكتهُ شايان توجه اين است كه در اين يزوهش نيز ارتباط مثبت و معنادارى بين تمام عاملهاى مقياس وابستكى به تمرين (از سر/• تا ع^/•) وجود داشت.

15. Exercise Dependence Scale-Revised (EDS-R)

https://jrsm.khu.ac.ir/ 


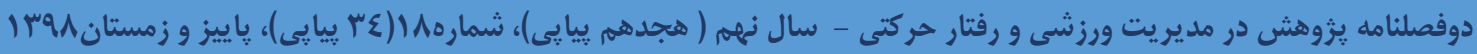

يافته هاى اخير نيز تأييد كننده اين فرضيه است كه عامل هاى مذكور از مفاهيم مشتركى برخوردارند و به همين دليل، با هم يك عامل مشترك سطح بالاتر را تشكيل مىدهند. بهعلاوه، همسانى درونى خردهمقياس علايم ترى ع//•، تدوام تمرين

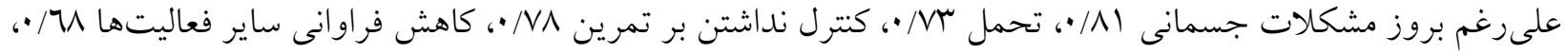

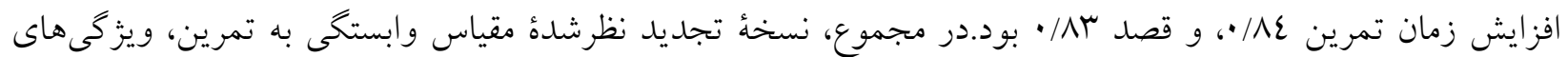
روانسنجى مطلوبى در فرهنگ اصلى و جند فرهنگ ديخر دارد. اما با عنايت به وجود فضاهاى متفاوت براى تمرين در كسترههاى ورزشى، الكَهاى مختلف مبتنى بر بافتار اجتماعى در تمرين، اثريذيرى مبتنى بر تفاوتهاى فرهنكى

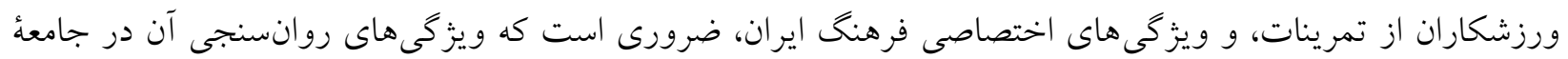
ايرانى بررسى شود. بر اين اساس، هدف نخست اين يزٔوهش، بررسى همسانى دروني نسخةٌ فارسى نسخهُ تجديد نظرشدهُ مقياس وابستكى به تمرين است و هدف دوم بررسى روايى ساختارى آن. هدف سوم نيز بررسى روايى ملاكى (از طريق روايى همزمان) با فرض ارتباط مثبت بين نسخهُ تجديد نظرشدهُ مقياس وابستكى به تمرين با مقياس تمايل به عضلانى بودن، يرسشنامهُ بررسى اختلال هاى خوردن، و يُرسشنامة اختلال عملكرد بود.

\section{روش شناسى بُزوهش}

يزٔوهش حاضر در جارجّوب طرح توصيفى و روانسنجى مبتنى بر همبستكى انجام شد. جامعهُ اين يزوهش، كلية ورزشكاران مرد رشتهُ يرورشاندام شهرستان گركان بود. به اين منظور، ..ع نفر از برورشاندامكاران مرد، به صورت نمونه گيرى

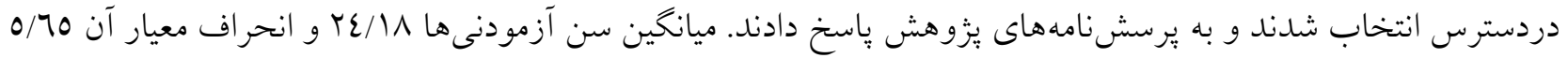

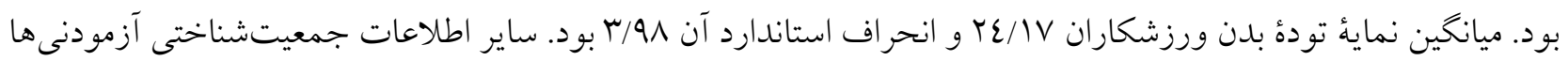
در جدول ا خزارش شده است.

جدول ا. اطلاعات جمعيتشناختى آزمودنى ها

\begin{tabular}{|c|c|c|c|}
\hline درصد & فراوانى & & متغير \\
\hline $11 / 4$ & ¿o & زير ديهم & تحصيلات \\
\hline (r/T & $1 \varepsilon 0$ & دييلم & \\
\hline$\varepsilon V / r$ & 119 & كارشناسى & \\
\hline $0 / \pi$ & YI & تحصيلات تكميلى & \\
\hline$r T / \mu$ & 179 & كمتر از ب ماه & ملدت زمان تمبين \\
\hline$r \cdot 10$ & NT & Lاه & \\
\hline$\Lambda / \mu$ & זr & r & \\
\hline$r T / O$ & $1 \mu$. & O To ماه و بيشتر & \\
\hline$\Lambda \mu / r$ & שחז & مجرد & وضعيت تأهل \\
\hline $17 / 0$ & 77 & متأهل & \\
\hline
\end{tabular}

https://jrsm.khu.ac.ir/ 


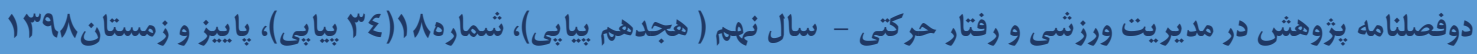

ابزار تردآورى اطلاعات

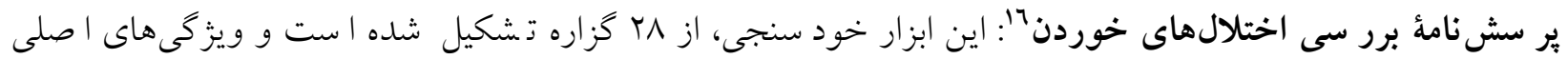
مربوط به اختلالهاى خوردن مانند تأكيد بيش از اندازه بر وزن و اندام، خوردن محدود، دورههاى برخورى، و رفتارهاى

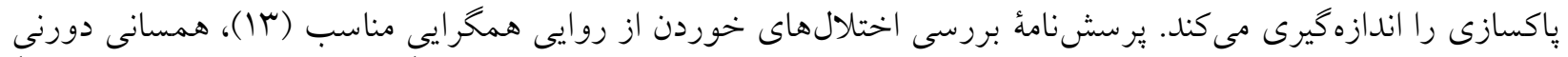
رضايتبخش (ع (1)، و اعتبار قابل قبولى (10) برخوردار است. در ايران نيز مولودى و همكاران (17) در مطالعهاى ضمن عر ضأ دادههاى هنجارى براى بر سشنامةٔ برر سى اختلالهاى خوردن در جمعيت ايرانى، هم سانى درونى بالا ( (1/•) و روايى همخرايى مناسبى را از طريق ارتباط نمرات برسشنامه با مقياس برخورى گزارش كردند.

ذسخهُ فار سى مقياس تجديد نظر شده وابستخى به تمرين ل: مقيا سى اب كزارهاى است كه نمرهذذارى آن به صورت مقياس درجابندى ليكرت است (از (ا(1) يعنى هركز تا (ا7) يعنى هميشه). هفت خردهمقياس دارد كه عبارتاند از تحمل، علايم ترك، تدوام تمرين به رغم بروز مشـكلات جســمانى، كنترل نداشـتن بر تمرين، كاهش فراوانى ســاير فعاليتها، افزايش زمان تمرين، و قصد. افرادى كه به اين مقياس باسخ مىدهند، در سه گروه جاى مى گيرند: ( (1) وابسته به تمرين، (Y) واجد برخى از علايم وابستخى به تمرين، و (Y) عارى از علايم وابستخى به تمرين. در ئزوهش هيل، روت، دلوني،

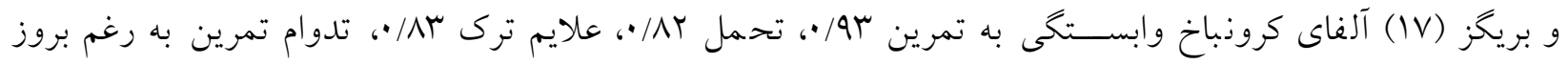

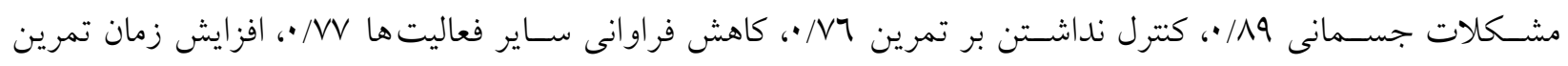

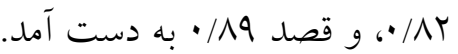
به منظور تهيه و آماده سـازى نسـخهُ فارسـى مقياس تجديد نظرشــدهُ وابسـتخى به تمرين، بس از كسـب اجازه از تدوين كنند كان مقياس تجديد نظر شدهُ واب ستخى به تمرين، به زبان فار سى ترجمه شد. سبِ، با توجه به نظر 0 تن از استادان روان شنا سى، ويرايش و آماده سازى اولّيه گرديد و در گام بعد، به زبان انخليسى بركردان شد. ذسخهُ فار سى و و

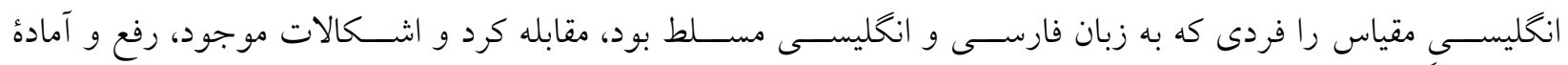

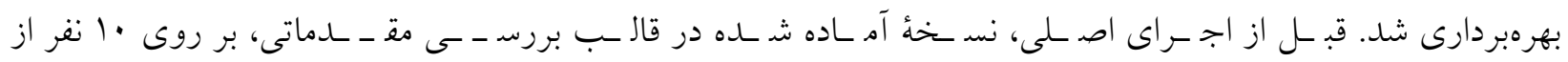

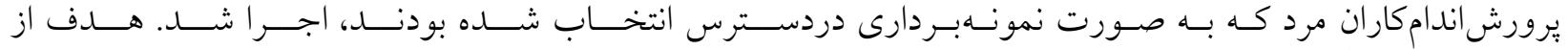

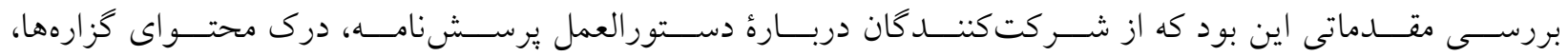

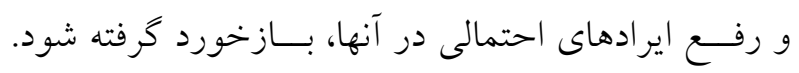

16. Eating Disorder Examination Questionnaire (EDE-Q)

17. Persian Version of Exercise Dependence Scale-Revised

https://jrsm.khu.ac.ir/ 


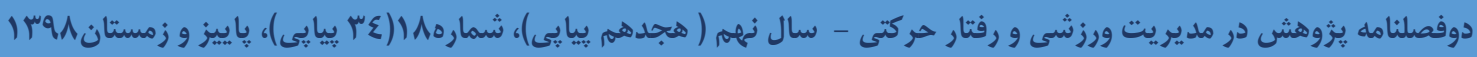

مقياس تمايل به عضلانى بودن^؛ اين مقياس براى سنجش نخرشها و رفتارهاى مربوط به عضلانى بودن تدوين شده است. نمره گذارى آن به صورت مقياس درجابندى ليكرت است (از (()) يعنى هركز تا (ا7)) يعنى هميشه). دو خردهمقياس

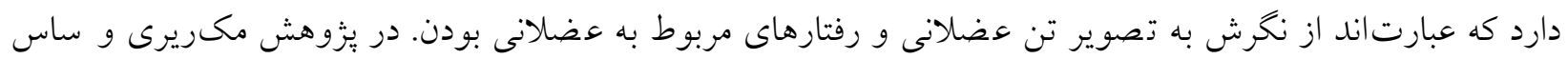
(1/)، براى مردان، همسانى درونى تمايل به عضلانى بودن كلى AV/•، نخرش به تصوير تن عضلانى MN/، و و رفتارهاى

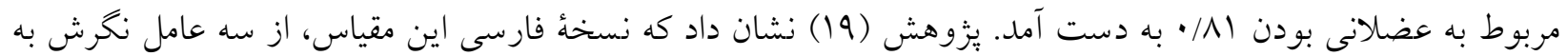
تصوير تن عضلانى، رفتارهاى مربوط به عضلانى بودن، و مصرف دارو براى يرورش عضلات تشكيل شده است. افزون بر اين، نشان داد از همسانى درونى و روايى همخرايى رضايتبخشى برخوردار است.

مقياس اختلال در عملكردو9! اين مقياس از 17 كزاره تشكيل شده است و براى اندازه گيرى اختلال در عملكرد روانى -

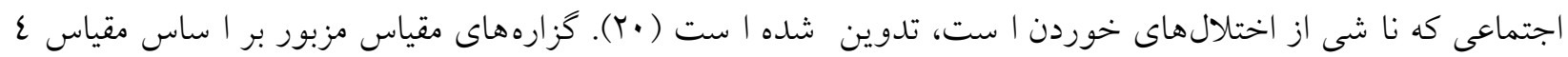
درجهاى نمرهگذارى مى شود (از (•) يعنى اصلاً تا (آ) يعنى زياد). يزّوهش بون و فيربرن (•r) ذشان داد كه اين مقياس از همسانى درونى، اعتبار آزمون- باز آزمون، و روايى ساختارى مناسبى برخوردار است. در ايران نيز مولودى و همكاران

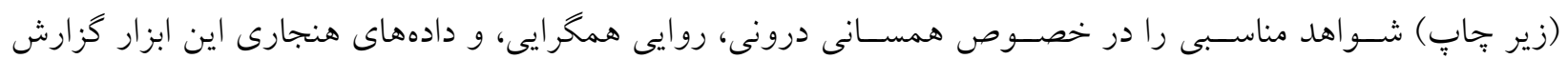

\section{شيوهُ كرد آورى اطللاعات}

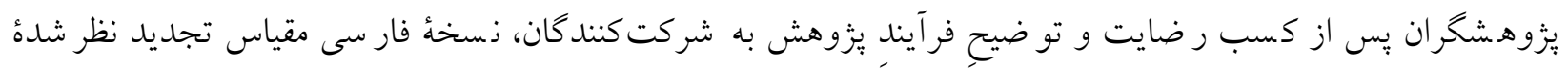
واب ستكى به تمرين، مقياس تمايل به ع ضلانى بودن، بر سش نامةٔ برر سى اختلال هاى خوردن، و بر سشنامهُ اختلال در

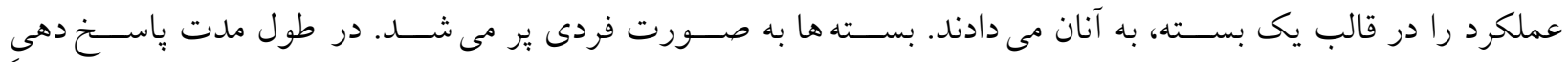
شركت كنند كان، يزوههشگران حضور فعال دا شتند تا از بروز يا سخهاى تصادفى جلو گيرى كنند و در صورت لزوم، به يرسش هاى شركت كنند كان بِاسخ دهند.

\section{روشهاى آمارى}

براى بررسى اعتبار نسخهُ فارسى مقياس تجديد نظرشدهُ وابستكى به تمرين، از روش هاى همسانى درونى استفاده شد. به منظور بررسسى روايى اين مقياس نيز از تحليل عاملى تأييدى، روايى ملاكى (از طريق روايى همزمان)، و همبسـتخى بين

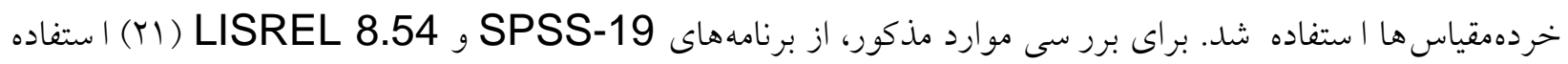

18. Drive for muscularity Scale (DMS)

19. Clinical Impairment Assessment (CIA)

https://jrsm.khu.ac.ir/ 


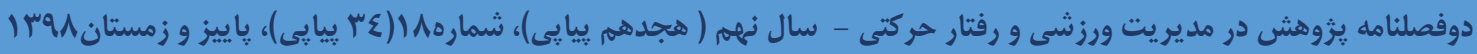

يافتهها

براى برر سى اعتبار نسخهُ فار سى مقياس تجديد نظر شدهُ وابستخى به تمرين، از روش همسانى درونى استفاده شد كه نتايج آن در جدول r مشاهده مىشود.

\begin{tabular}{|c|c|}
\hline آلفاى كرونباخ & خردمقياس \\
\hline$\cdot N V$ & 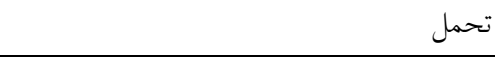 \\
\hline •/AY & علايم ترك \\
\hline$\cdot / 11$ & تدوام تمرين علىرغم بروز مشكلات جسمانى \\
\hline$\cdot / \Lambda \cdot 1$ & كنترل نداشتن بر تمرين \\
\hline$\cdot N V$ & كاهش فراوانى ساير فعاليتها \\
\hline$\cdot \mathrm{rV}$ & افزايش زمان تمرين \\
\hline$\cdot N 7$ & قصد \\
\hline$\cdot / \Lambda 1$ & 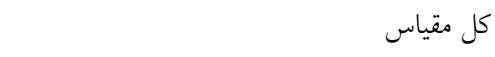 \\
\hline
\end{tabular}

نتايج جدول r نشان مىدهد كه ضرايب آلفاى كرونباخِ به دست آمده، از نظر روانسنجى براى تمام خرده مقياسها رضايتبخش است. به منظور بررسى روايى مقياس تجديد نظر شده وابستخى به تمرين نيز از تحليل عاملى تأييدى، روايى

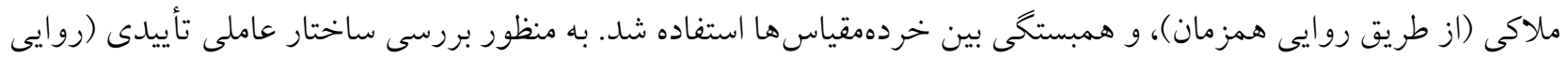
سازه) نسخهُ فارسى مقياس تجديدنظر شدهُ وابستكى به تمرين از تحليل عاملى تأييدى با روش حداكثر درستنمايى در سطح ماتريس واريانس كواريانس استفاده شد (نخاه كنيد به جورسكوى و سوربوم (YI)). نتايج آزمونهاى ميزان كفايت

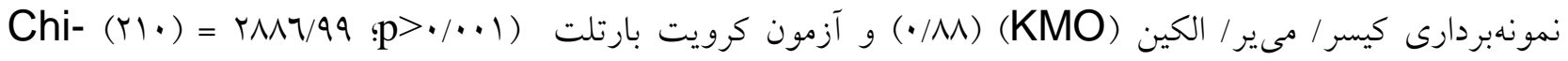
حاكى از مطلوب بودن حجم نمونه و توانايى عامل شدن كزارههاى مقياس بود. به منظور برازش كامل مدل با با بـ (Square دادهها سعى شد با آزاد كردن برخى بارامترها بر اساس شاخصهاى تعديل، مدل بهبود يابد. از اين رو، بر مبناى شاخصهاى بيشنهادى مدل، زيربناى نظرى نسخهُ اصلى مقياس تجديدنظر شدهُ وابستكى به تمرين و در نظر كرفتن همبستكى بين عامل هاى به دست آمده، يارامترهاى متعددى آزاد شد. نمودار مسير تحليل عاملى تأييدى بعد از آزاد شدن اين پارامترها

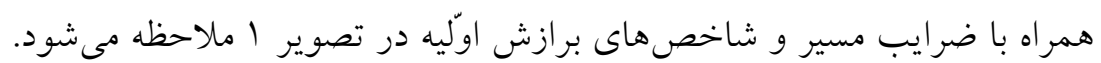

https://jrsm.khu.ac.ir/ 


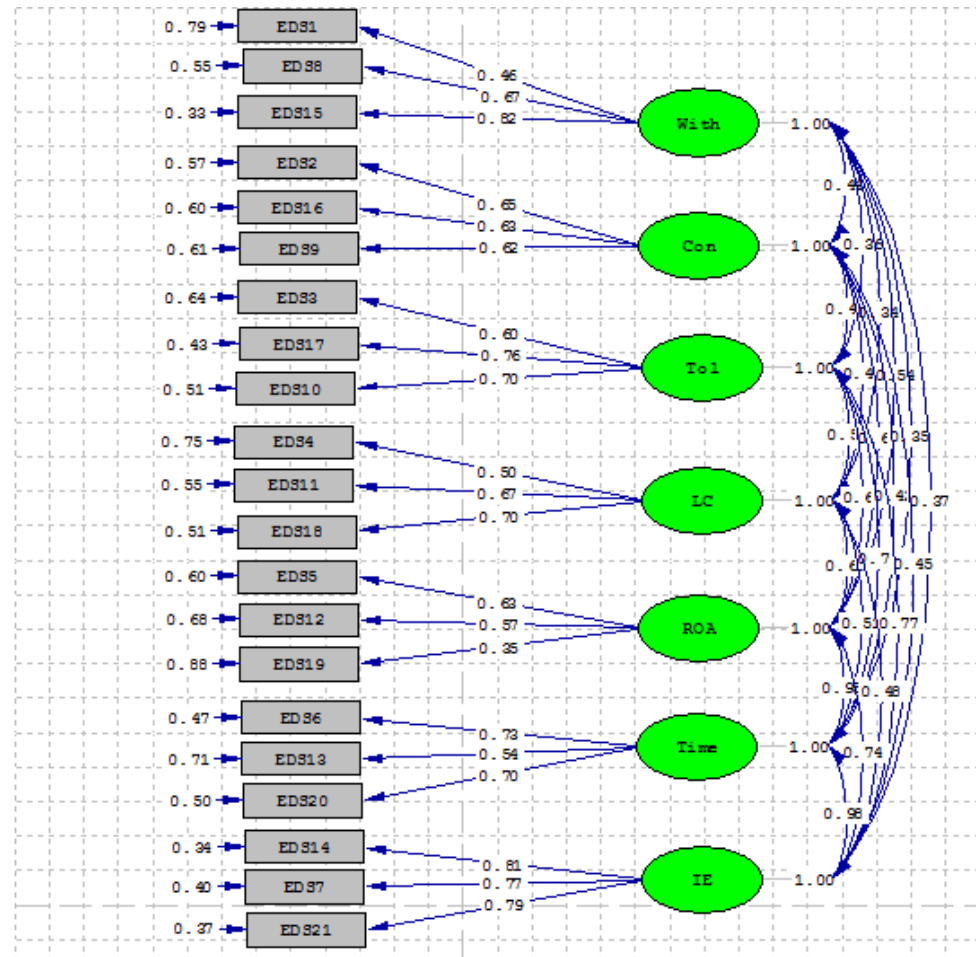

Chi-Square $=388.22, d f=168, P$-value $=0.00000, \quad$ RMSEA $=0.057$

تصوير ا. نمودار ضر ايب مسير ساختار عاملى نسخهُ فارسى مقياس تجديدنظر شده وابستىى به تمرين

در مرحلة بعد، برازندگى الخو بر اساس شاخص مجذور خى، شاخص برازندگى تطبيقى (CFI)، شاخص هنجارشده

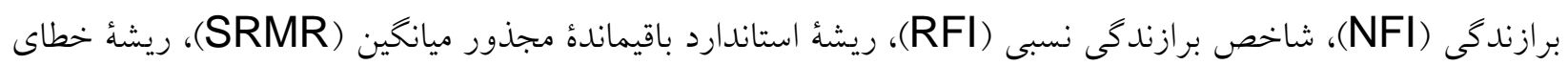
ميانخين مجذورات تقريب (RMSIA)، شـاخص نيكويى برازش (GFI) و ملاك اطلاعات آكايكى (AIC) مورد بررسى قرار كرفت كه نتايج آنها در جدول ب مشاهده مىشود. جدول ك. شاخصهاى برازش تحليل عامل تأييدى نسخهُ فارسى مقياس تجديدنظر شده وابستخى به تمرين

\begin{tabular}{|c|c|c|c|c|c|c|c|c|}
\hline AIC & REMSEA & SRMR & GFI & RFI & NFI & CFI & Df & مجذور خى \\
\hline$V \cdot r N / q \mu$ &.$/ .0 \mathrm{~V}$ & $\cdot / \cdot \sum Y$ &.$/ 9 Y$ &.$/ 94$ &.$/ 90$ & $\cdot / 9 \mathrm{~V}$ & 171 & rV々/TV \\
\hline
\end{tabular}

شاخص هاى برازندگى تطبيقى (CFI)، برازندگى هنجارشده (NFI)، برازندگى نسبى (RFI)، و نيكويى برازش (GFI) هر جقدر به يكى نزديكتر باشد از برازش مطلوبتر الكو حكايت دارد. هرجند براى برر سى نيكويى برازش معمولاً از شاخص مجذور خى استفاده مى شود، مجذور خى با افزايش حجم نمونه و درجة آزادى افزايش مىيابد. به همين دليل،

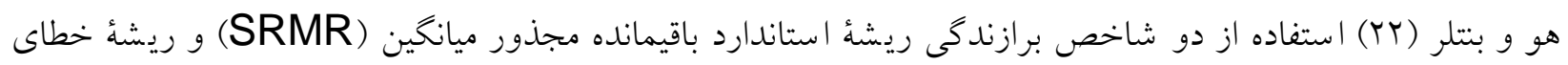
ميانخين مجذورات تقريب (RMSIA) را تو صيه نمودهاند. به اعتقاد شرميله- انگل، مو سبروگر، و مولر (T) مقادير 


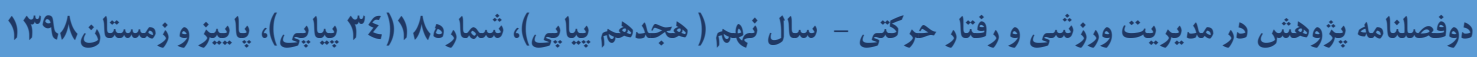

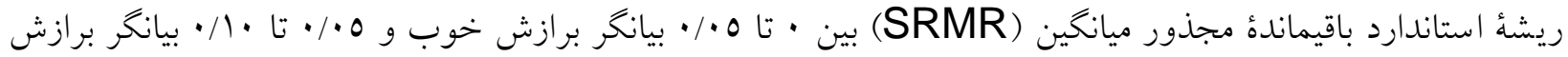
قابل قبول مدل است. همجنين، مقادير ريشهُ خطاى ميانگين مجذورات تقريب (RMSIA) بين · تا ه • • بيانگر برازش خوب و ه•• • • ^••• بيانگر برازش قابل قبول است. بنابراين، با توجه به اعداد جدول عو ضرايب استاندارد شده و شـاخص تى، مى توان كفت كه مدل تأييدى از برازش قابل قبولى برخوردار اسـت. در جدول ع، نتايج تحليل عاملى تأييدى مشاهله مى شود.

جدول ع. ضرايب استاندارد و شاخص تى تحليل عاملى تأييدى نسخةٌ فارسى مقياس تجديدنظر شدة وابستخى به تمرين

\begin{tabular}{|c|c|c|c|}
\hline شاخص تى & استاندارد & كزارهها & خردمنقياس \\
\hline $\begin{array}{l}\Lambda / \varepsilon \varepsilon \\
|r / \varepsilon| \\
\mid \varepsilon / v\end{array}$ & $\begin{array}{l}\cdot / 27 \\
\cdot / 7 V \\
\cdot / 7 Y\end{array}$ & 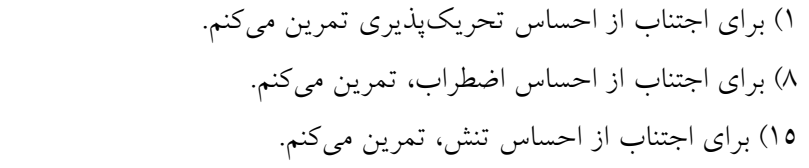 & تحمل \\
\hline $\begin{array}{l}11 / 19 \\
11 / 29 \\
11 / \mu r\end{array}$ & $\begin{array}{l}\cdot / 70 \\
\cdot / 7 r \\
\cdot / 7 r\end{array}$ & 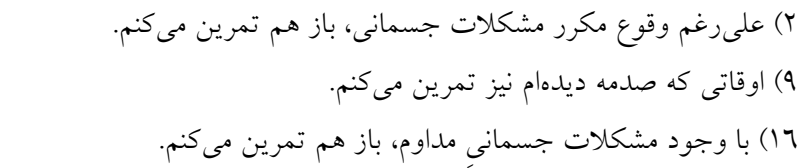 & علايم ترى \\
\hline $\begin{array}{l}11 / 9 r \\
10 / 1\end{array}$ & $\begin{array}{l}\cdot / 7 \\
\cdot / N 7 \\
\cdot / v\end{array}$ & 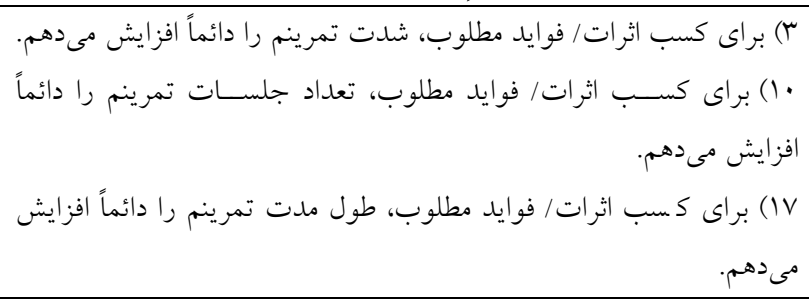 & 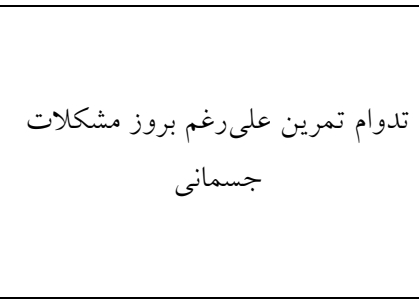 \\
\hline $\begin{array}{l}9 / 91 \\
1 T / 2 \\
1 T / \wedge 9\end{array}$ & $\begin{array}{l}\cdot / 0 \\
\cdot / 7 V \\
\cdot / V\end{array}$ & 11) قادر به كاهش طول مدت تمر ينم نيستم. & كتترل نداشتن بر تمرين \\
\hline $\begin{array}{l}1 . / 94 \\
7 / 01\end{array}$ & $\begin{array}{l}\cdot / 74 \\
. / 0 \mathrm{~V} \\
. / 40\end{array}$ & 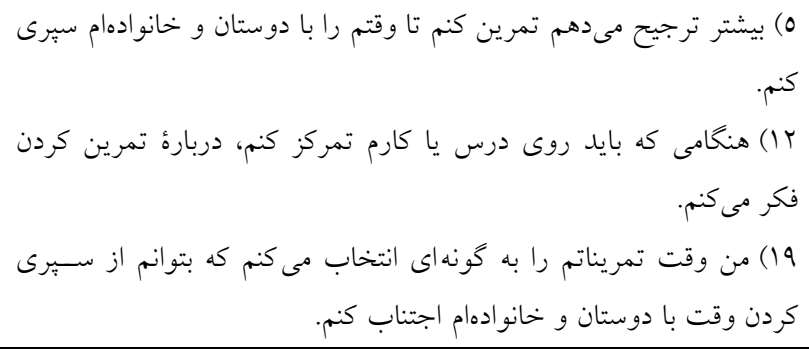 & كاهش فراوانى ساير فعاليتها \\
\hline $\begin{array}{l}10 / 10 \\
11 / 1 \\
10 / T V\end{array}$ & $\begin{array}{l}\cdot / N r \\
\cdot / 02 \\
\cdot / N\end{array}$ & 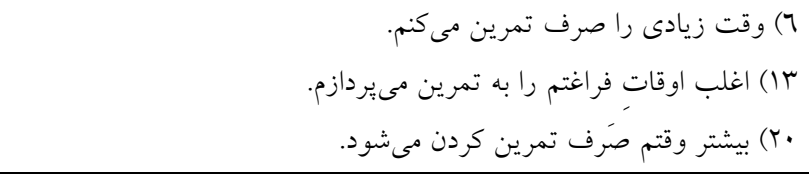 & افزايش زمان تمرين \\
\hline $\begin{array}{l}1 / / 94 \\
1 / 07 \\
1 N / 19\end{array}$ & $\begin{array}{l}\cdot / \mathrm{Nl} \\
\cdot / \mathrm{NV} \\
\cdot / \mathrm{VQ}\end{array}$ & 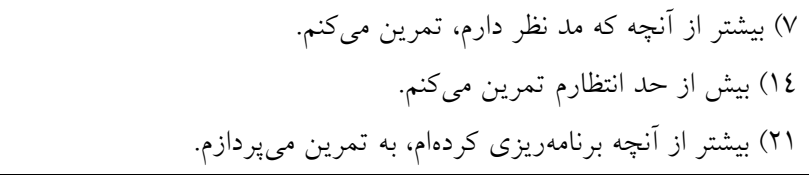 & قصد \\
\hline
\end{tabular}

https://jrsm.khu.ac.ir/ 


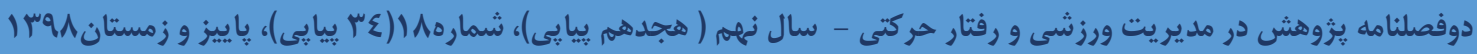

به منظور بررسى روايى همزمان نسخهُ فارسى نسخهُ تجديد نظرشدهُ مقياس وابستكى به تمرين، همبستكى اين مقياس با مقياس تمايل به عضلانى بودن، يرسشنامةٔ بررسى اختلالهاى خوردن، و يرسش نامهُ اختلال عملكرد بررسى شد (جدول 0). علت انتخاب اين ابزارها آن بود كه بين تمايل به عضلانى بودن و وابستخى به تمرين، ارتباط مثبت و معنادارى وجود دارد (1) (1) و مبتلايان به اختلالهاى خوردن، در ورزش كردن، افراط مىكنند (•l). نتايج يزوهش نشان داد كه تمام خردممقياسهاى مقياس تمايل به عضلانى بودن با تمام خردهمقياسهاى نسخهُ تجديد نظرشده مقياس وابستكى به تمرين ارتباط مثبت و معنادارى دارد. يخانه استثنا در اين مورد، نبود ارتباط بين خردهمقياسهاى مصرف دارو براى يرورش عضلات و كنترل نداشتن بر تمرين بود. خردممقياسهاى يرسشنامهُ بررسى اختلال هاى خوردن نيز با خردممقياسهاى نسخئ تجديد نظرشده مقياس وابستكى به تمرين ارتباط مثبت و معنادارى دارد (به جز نبود ارتباط بين نكرانى دربارهُ وزن با تداوم تمرين به رغم بروز مشكلات جسمانى و نبود ارتباط بين خوردن محدود با تداوم تمرين به رغم بروز مشكلات جسمانى، كنترل نداشتن بر تمرين، و قصد) ارتباط مثبت و معنادارى را نشان داد. در نهايت، نتايج نشان داد كه خردممقياسهاى نسخهُ تجديد نظرشدهُ مقياس وابستكى به تمرين با برسش نامهُ اختلال عملكرد، رابطةٌ مستقيم و معنادارى دارد. الكوى

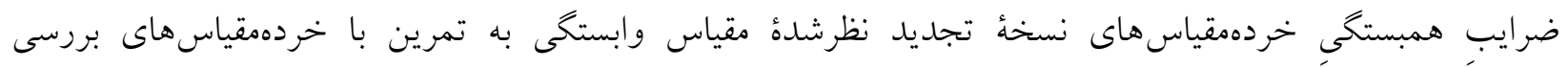
اختلالهاى خوردن، تمايل به عضلانى بودن، و برسشنامة اختلال عملكرد، نمودار روايي همزمان خوبِ نسخهُ فارسي مقياس تجديد نظرشده وابستخى به تمرين است. 
جدول 0. ماتريس ضرايب همبستكى بين خردهمقياسهاى نسخةُ تجديد نظرشده مقياس وابستكى به تمرين با مقياس اختلال در عملكرد و خردهمقياس هاى يرسشنامة بررسى اختلال هاى خوردن و مقياس تمايل به عضلانى بودن

\begin{tabular}{|c|c|c|c|c|c|c|c|c|c|}
\hline \multicolumn{10}{|c|}{ مقايس تجديد نظرشدهُ وابستخى به تمرين } \\
\hline مقياس & قصد & تمزانِ & كاير فعاليتها فراني & بد بد تمترن & به بد رغم بروز تمرين & ترى & تحمل & & \\
\hline$\cdot / 2 \Upsilon^{* * * * *}$ & $\cdot / \mathrm{V}$ **** & $\cdot N \varepsilon^{* * *}$ & $\cdot \pi 0^{* * * * 3}$ & $\cdot / r V^{* * *}$ & $\cdot / Y 7^{* * * *}$ & $\cdot / / V^{* * * *}$ & $\cdot \pi 0^{* * *}$ & كل مقياس & تمضايل به \\
\hline$\cdot / T^{* * * * *}$ & $\cdot / r \varepsilon^{* * *}$ & $\cdot / 19 \%$ & $\cdot / r 7^{* * * *}$ & $\cdot / T \varepsilon^{* * * *}$ & $\cdot / / V^{* * * *}$ & $\cdot / / \varepsilon^{* * *}$ & $\cdot / \Gamma \Lambda^{* * *}$ & تصوير تن به & \\
\hline$\cdot / 2 q^{* * * *}$ & $\cdot / q^{* * *}$ & $\cdot / \varepsilon \varepsilon * *$ & $\cdot \pi \Lambda^{* * *}$ & $\cdot / T^{* * * * *}$ & $\cdot / \Gamma I^{* * * *}$ & 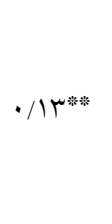 & $\cdot /\left.\varepsilon\right|^{* * *}$ & مربوط بهار به بونى & \\
\hline$\cdot / / V^{* * *}$ & $\cdot / \cdot r^{* *}$ & $\cdot / 17^{* * *}$ & $\cdot / \Lambda^{* * * *}$ & $\cdot / \cdot \varepsilon$ & $\cdot / 10^{* * * * 3}$ & $\cdot / r^{* * * *}$ & $\cdot 1 \cdot 9^{*}$ & مصرف داى برورش & \\
\hline$\cdot / T V^{* * * *}$ & $\cdot / 19^{* * *}$ & $\cdot / \Lambda^{* * *}$ & $\cdot / r^{* * * *}$ & $\cdot / 17^{* * *}$ & $\cdot / 1 \cdot 9^{*}$ & $\cdot /$ row* & $\cdot / \pi \mu^{\mu * *}$ & خوردنِ كل اخلال & 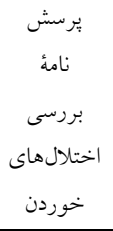 \\
\hline$\cdot / \pi \varepsilon^{* * * *}$ & $\cdot / \Lambda^{* * *}$ & $\cdot / 19^{* * *}$ & $\cdot / r \cdot V^{* * *}$ & 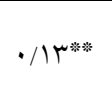 & $\cdot / 1 \cdot 9^{*}$ & $\cdot / \Lambda \Lambda^{* * * *}$ & $\cdot / \Lambda^{* * *}$ & نخر انى دربارة & \\
\hline$\cdot / r^{* * * *: *}$ & $\cdot / 17^{* * *}$ & $\cdot / 1 r^{* * *}$ & $\cdot / V^{* * *}$ & $\cdot / / V^{\text {絭絭 }}$ & 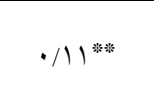 & $\cdot / r I^{* * * *}$ & $\cdot / 19^{* * *}$ & نغر انى دربارة & \\
\hline$\cdot / r \varepsilon^{* * * *}$ & $\cdot / Y^{* * *}$ & $\cdot 110^{* * *}$ & $\cdot / / V^{* * *}$ & $\cdot / 17^{* * * *}$ & $.1 \cdot 7$ & $\cdot / \pi r^{*} * *:$ & $\cdot / r I^{* *}$ & نغر انى دربارة & \\
\hline$\cdot / 11^{* * * *}$ & $\cdot / \cdot \varepsilon$ & $.1 .9^{*}$ & $\cdot / 11^{* * * *}$ &.$/ \cdot Y$ & .1 .0 & $\cdot / r^{* * * *}$ & $\cdot / 1 \cdot 1 *$ & خحوردن & \\
\hline • & $\cdot / T^{* * *}$ & $\cdot / 17^{* * *}$ & $\cdot \pi r^{* * * * *}$ & $\cdot / 19^{* * * *}$ & $\cdot / 19^{* * *}$ & $\cdot / \pi 7^{* * * *}$ & $\cdot / 19^{* * *}$ & & نامة إرسلال \\
\hline
\end{tabular}




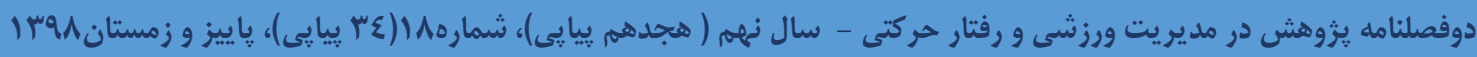

الكوى ضر ايب همبستخى بين خردهمقياس هاى نسخهُ فارسى مقياس تجديد نظرشدهُ وابستحى به تمرين در جدول 7، نشان مىدهد كه روابط درونى خوبى بين خردهمقياسها وجود دارد. جدول 7. ماتريس ضر ايب همبستخى بين خردهمقياسهاى نسخؤ تجديد نظرشدة مقياس وابستىى به تمرين

\begin{tabular}{|c|c|c|c|c|c|c|c|c|}
\hline$\wedge$ & v & 7 & 0 & $\varepsilon$ & r & r & 1 & خردهمقياس \\
\hline & & & & & & & 1 & تحمل (1) \\
\hline & & & & & & 1 & $\cdot / \pi \xi * m$ & علايم ترى (Y) \\
\hline & & & & & 1 & $\cdot / r q^{* * *}$ & 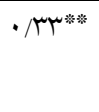 & تداوم تمرين به رغم بروز \\
\hline & & & & 1 & $\cdot / r^{* * * 3}$ & $\cdot / r r^{* *: m}$ & $\cdot / \varepsilon r^{* * m}$ & كتترل نداشتن بر تمرين (ع) \\
\hline & & & 1 & $\cdot / \varepsilon Y^{* * a}$ & $\cdot / \pi 7^{* * * *}$ & $\cdot / r^{* * * * *}$ & $\cdot / \varepsilon \varepsilon^{* * * *}$ & كاهش فراواني ساير فعاليتها \\
\hline & & 1 & $\cdot 109^{* * *}$ & $\cdot / 47^{* * *}$ & $\cdot / 4^{* * *}$ & $\cdot / r^{\mu *: *}$ & $\cdot 10 \varepsilon^{* * *}$ & |فزايش زمان تمرين (7) \\
\hline & 1 & $\cdot / N^{\mu * * * *}$ & $\cdot 101^{* \text { ** }}$ & • & $\cdot \mid \pi r^{* * * 3}$ & $\cdot / r 0^{* * h}$ & $.109^{* *}$ & قصد (V) \\
\hline 1 & $\cdot / V \Lambda^{* * * 3}$ & $\cdot / V^{* * *}$ & $\cdot / V \varepsilon^{* * * 3}$ & $\cdot / \neg \Sigma^{* * *}$ & $\cdot / 7 T^{\text {**: }}$ & $\cdot /\left.0\right|^{* * h}$ & $\cdot / 7 T^{* * *}$ & كل مقياس (^) \\
\hline
\end{tabular}

$\left.{ }^{* *} \mathrm{P}<\cdot / \cdot\right)^{*} \mathrm{P}<\cdot / \cdot 0$

\section{بحث و نتيجه تيرى}

هدف از يزوهش حاضر، بررسى روايى و اعتبار نسخه فارسى مقياس تجديد نظر شده وابستخى به تمرين در ميان يرورشاندام كاران مرد بود. در بعد بررسى اعتبار نسخهُ تجديد نظرشدهُ مقياس وابستكى به تمرين، دامنهُ ضرايب آلفاى

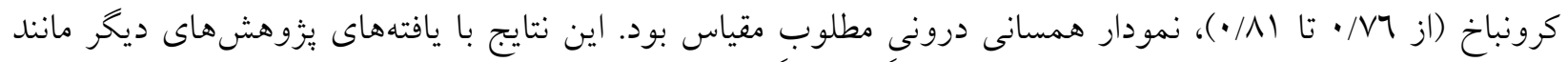
داونز و همكاران (^) و سيسيليا و گونزالس-كوتره (r) (1)، باراستاتيدو و همكاران (9)، و كاستا، كوتسوكريا، هازنبلاس، لاركان، و اليوا (Yr) كه اعتبار خوبى را براى نسخهُ تجديد نظرشدهُ مقياس وابستحى به تمرين گزارش كردهاند، مطابقت دارد. با اين حال، برخلاف اغلب يزوهشها (براى مثال، ليندوال و پالميرا (Yd)) كه بر حسب اعتبار پايين، خردهمقياس كاهش فراوانى ساير فعاليتها را مسألهسازترين خردهمقياس معرفى كردهاند، نتايج اين يزوهش نشان داد كه خردهمقياس كاهش فراو انى ساير فعاليتها، از اعتبار مطلوبى برخوردار است.

در يزوهش حاضر، براى بررسى ساختار عاملى تأييدى (روايى سازه) نسخهُ فارسى مقياس تجديد نظرشدهُ وابستخى به تمرين، از تحليل عاملى تأييدى استفاده شد. نتايج تحليل عاملى از الكوى V عاملى نسخهُ فارسى مقياس تجديد نظرشدهُ وابستكى به تمرين حمايت كرد. اين نتايج، با نتايج يزوهش هاى آلكرى و ترمى (9)، ليندوال و يالميرا (Y)، سيسيليا و كونزالس -كوتره (Y (1)، يُراستاتيدو و همكاران (9)، كاستا و همكاران (YY)، و مولر و همكاران (•(1) همسوست. از اين 


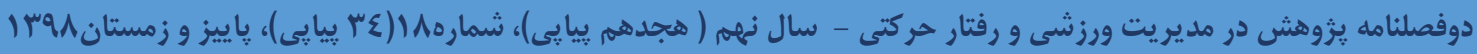

رو، نتايج يزوهش حاكى از آن است كه هفت عامل نسخهُ تجديد نظرشدهُ مقياس وابستخى به تمرين، مىتوانند سازه وابستخى به تمرين را اندازهيرى كنند.

تجزيه و تحليل هاى مربوط به روايى همزمان نسخهُ فارسى مقياس تجديد نظرشدهُ وابستكى به تمرين نشان داد كه اين ابزار با مقياس تمايل به عضلانى بودن ارتباط مثبت و معنادارى دارد. اين يافتهها را مىتوان تأييدكنندهُ نتايجى در نظر كرفت كه ارتباط مثبت و معنادارى را بين تمايل به عضلانى بودن و وابستكى به تمرين كزارش كردهاند (براى مثال، مكىريرى و ساس (1))؛ ريكسياردلى و مككيب (YY)؛ آربور و مارتين-كينس (YV)؛ بل، دورش، مكريرى، و هاوى

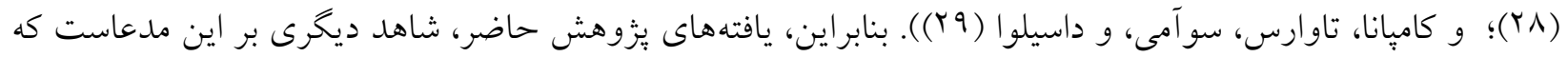
مفاهيم تمايل به عضلانى بودن و وابستخى به تمرين از لحاظ نظرى با همديخر مرتبط هستند. افزون بر اين، نتايج نشان داد كه خردهمقياسهاى نسخهُ تجديد نظرشدهُ مقياس وابستكى به تمرين با نمره كلى برسشنامة بررسى اختلالهاى خوردن ارتباط مثبت و معنادارى دارد. اين نتايج با يافتهاى مولر و همكاران (• (1) در آلمان همسوست و مهر تأييدى بر اين موضوع است كه برخى از مبتلايان به اختلالهاى خوردن، براى كاهش وزن يا جلو گيرى از اضافهوزن، به تمريناتِ ورزشى مفرط رو مى آورند (·r). با اين حال، خردهمقياس خوردن محدود با خردممقياسهاى نسخه تجديد نظرشده مقياس وابستكى به تمرين ارتباط جندانى ندارد. با توجه به يافتهُ اخير، به نظر مىرسد كه مبتلايان به وابستكى به تمرين، براى كاهش وزن يا جلو گيرى از افزايش وزن، به طور افراطى تمرين مى كنند نه اينكه غذاى خود را محدود نمايند. ارتباط مشت و معنادار خردهمقياسهاى نسخهُ تجديد نظرشدهُ مقياس وابستكى به تمرين با برسشنامُٔ اختلال در عملكرد، حاكى از آن است وابستخى به تمرين، واجد يكى از مهمترين ملاكهاى تشخيصى اختلال روانى است؛ جون عملكردهاى فرد را در حوزههاى مختلف (ماند شغل و روابط بين فردى) مختل مى كند.تمام خردهمقياسهاى نسخهُ تجديد نظرشدهُ مقياس وابستخى به تمرين همبستكى مثبت و معنادارى با يكديخر داشتند، اما همبستخى بسيار بالايى بين آنها ديلده نشد. در نتيجه، مسائل مربوط به روايى افتراقى وجود ندارد (Y)). از سوى ديگر، نتايج مذكور اين احتمال را مطرح مى كند كه هفت

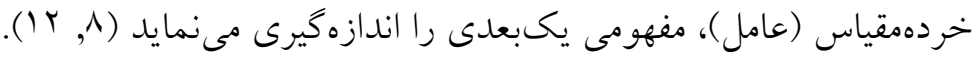

نتايج يزوهش حاضر، به طور كلى، حمايتهاى اولّيه را در خصوص روايى و اعتبار مناسب نسخهُ تجديد نظرشدهُ مقياس وابستكى به تمرين در جمعيت ايرانى فراهم مى كند. با اين حال، نتايج مزبور بايد با توجه به محدوديتهاى آن تفسير شود، محدوديتهايى كه در ادامه به آنها اشاره مىشود. نخست اينكه نمونهُ يزوهش از ورزشكاران مرد رشتهُ يرورشاندام تشكيل شده بود، در نتيجه، اين نتايج را نمىتوان به ورزشكاران زن اين رشته يا ورزشكاران رشتهاى ديخر تعميم داد.

https://jrsm.khu.ac.ir/ 


$$
\text { اين موم اينكه همسانى دروني برخى از خردممقياس هاى وابستخى به تمرين، متوسط بود. به همين دليل، براى بررسى اعتبارِ }
$$

1. Biddle SJ, Mutrie N. Psychology of physical activity: Determinants, well-being and interventions: Routledge; 2007.

2. Shafabakhsh SR, Shafizadeh M, Dehkhoda MR. Effects of training and Fitness Education on the Health-Related Physical Fitness Factors in Adolescent Students: Evaluating the Mediating Role of Knowledge and Internal Motivation. Journal of Research in Sport Management \& Motor Behavior. 2012;2(3):1-14.

3. Farrokhi A, Aghasi Brojeni S, Motesharee E, Farahani A. The Relationship and Comparison between Perfectionism andMood States of Team and Individual Sports Athletes. Journal of Research in Sport Management \& Motor Behavior. 2012;2(3):111-23.

4. Hausenblas HA, Downs DS. How much is too much? The development and validation of the exercise dependence scale. Psychology and Health. 2002;17(4):387-404.

5. Pasman L, Thompson JK. Body image and eating disturbance in obligatory runners, obligatory weightlifters, and sedentary individuals. International Journal of Eating Disorders. 1988;7(6):759-69.

6. Davis C, Brewer H, Ratusny D. Behavioral frequency and psychological commitment: Necessary concepts in the study of excessive exercising. Journal of behavioral medicine. 1993;16(6):611-28.

7. Ogden J, Veale D, Summers Z. The development and validation of the Exercise Dependence Questionnaire. Addiction Research \& Theory. 1997;5(4):343-55.

8. Downs DS, Hausenblas HA, Nigg CR. Factorial validity and psychometric examination of the exercise dependence scale-revised. Measurement in physical education and exercise science. 2004;8(4):183-201.

9. Allegre B, Therme P. [Confirmative study of a French version of the Exercise Dependence Scale-revised with a French population]. L'Encephale. 2008;34(5):490-5.

10. Müller A, Claes L, Smits D, Gefeller O, Hilbert A, Herberg A, et al. Validation of the German version of the exercise dependence scale. European Journal of Psychological Assessment. 2013.

11. Parastatidou IS, Doganis G, Theodorakis Y, Vlachopoulos SP. Addicted to exercise: Psychometric properties of the Exercise Dependence Scale-Revised in a sample of Greek exercise participants. European Journal of Psychological Assessment. 2012;28(1):3-10.

12. Sicilia Á, González-Cutre D. Dependence and physical exercise: Spanish validation of the Exercise Dependence Scale-Revised (EDS-R). The Spanish journal of psychology. 2011;14(01):421-31.

13. Fairburn CG, Beglin SJ. Assessment of eating disorders: Interview or self-report questionnaire? International Journal of Eating Disorders. 1994;16(4):363-70.

14. Mond JM, Hay PJ, Rodgers B, Owen C, Beumont P. Validity of the Eating Disorder Examination Questionnaire (EDE-Q) in screening for eating disorders in community samples. Behaviour research and therapy. 2004;42(5):551-67.

15. Luce $\mathrm{KH}$, Crowther $\mathrm{JH}$. The reliability of the eating disorder examination-Self-report questionnaire version (EDE-Q). International Journal of Eating Disorders. 1999;25(3):34951. 
16. Moloodi R, Mahmoodi, M., Ghaderi, A., et al. Persian version of Eating Disorder Examination Questionnaire and Clinical Impairment assessment: norms and psychometric properties for undergraduate women. Iranian Journal of Psychiatry. in press.

17. Hale BD, Roth AD, DeLong RE, Briggs MS. Exercise dependence and the drive for muscularity in male bodybuilders, power lifters, and fitness lifters. Body Image. 2010;7(3):234-9.

18. McCreary DR, Sasse DK. An exploration of the drive for muscularity in adolescent boys and girls. Journal of American college health. 2000;48(6):297-304.

$$
\begin{aligned}
& \text { 19. مولودى ر, نونهال س, سامان, دادخواه ا, دادخواه ا. كفايت روان سنجى نسخه ف فارسى مقياس تمايل به } \\
& \text { عضلانى بودن در ورزشكاران مرد رشته ى برورش اندام شهرستان گركان. فصلنامه علمى -يزوهشى روشها }
\end{aligned}
$$

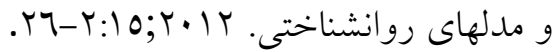

20. Bohn K, Fairburn CG. The clinical impairment assessment questionnaire (CIA). Cognitive Behavioral Therapy for Eating Disorders. 2008.

21. Jöreskog KG, Sörbom D. LISREL 8.54. Structural equation modeling with the Simplis command language. 2003.

22. Hu Lt, Bentler PM. Cutoff criteria for fit indexes in covariance structure analysis: Conventional criteria versus new alternatives. Structural equation modeling: a multidisciplinary journal. 1999;6(1):1-55.

23. Schermelleh-Engel $\mathrm{K}$, Moosbrugger $\mathrm{H}$, Müller $\mathrm{H}$. Evaluating the fit of structural equation models: Tests of significance and descriptive goodness-of-fit measures. Methods of psychological research online. 2003;8(2):23-74.

24. Costa S, Cuzzocrea F, Hausenblas H, Larcan R, Oliva P. Psychometric examination and factorial validity of the Exercise Dependence Scale-Revised in Italian exercisers. Journal of Behavioral Addictions. 2012;1(4):186-90.

25. Lindwall M, Palmeira A. Factorial validity and invariance testing of the Exercise Dependence Scale-Revised in Swedish and Portuguese exercisers. Measurement in Physical Education and Exercise Science. 2009;13(3):166-79.

26. Ricciardelli LA, McCabe MP. A longitudinal analysis of the role of biopsychosocial factors in predicting body change strategies among adolescent boys. Sex Roles. 2003;48(78):349-59.

27. Arbour K, Martin-Ginis K, editors. Lifting satisfaction: The relationship between young men's weight-training participation, muscle building confidence, and behavior. Proceedings of the annual meeting of the Canadian Society for Psychomotor Learning and Sport Psychology; 2004.

28. Bell A, Dorsch KD, Mccreary DR, Hovey R. A look at nutritional supplement use in adolescents. Journal of Adolescent Health. 2004;34(6):508-16.

29. Campana ANNB, Tavares MdCGCF, Swami V, da Silva D. An examination of the psychometric properties of Brazilian Portuguese translations of the Drive for Muscularity Scale, the Swansea Muscularity Attitudes Questionnaire, and the Masculine Body Ideal Distress Scale. Psychology of Men \& Masculinity. 2013;14(4):376.

30. Association AP. Diagnostic and Statistical Manual of Mental Disorders (DSM-5®): American Psychiatric Pub; 2013. 